Western University Scholarship@Western

Law Publications

Law School

6-8-1997

\title{
Do Canadian Children have a Right to be Intellectually Free?
}

Margaret Ann Wilkinson

Western University, mawilk@uwo.ca

Lynne McKechnie

Follow this and additional works at: https://ir.lib.uwo.ca/lawpub

Part of the Law Commons

Citation of this paper:

Wilkinson, Margaret Ann and McKechnie, Lynne, "Do Canadian Children have a Right to be Intellectually Free?" (1997). Law Publications. 80.

https://ir.lib.uwo.ca/lawpub/80 


\title{
Do Canadian children have a right to be intellectually free?/ Existe-t-il un droit de liberté intellectuelle pour les enfants au Canada?
}

\author{
Lynne (E.F.) McKechnie ${ }^{1}$ \\ Graduate School of Library and Information Science \\ Margaret Ann Wilkinson ${ }^{1}$ \\ Graduate School of Library and Information Science, and Faculty of Law \\ University of Western Ontario \\ <emckech1@julian.uwo.ca> \\ <lawmaw@uwoadmin.uwo.ca>
}

The purpose of this study is to examine some aspects of the issue of children's access to information through public libraries in Canada. Voluntary professional codes of ethics and intellectual freedom manifestos of the American and Canadian Library Associations, as well as current commentary and reported practices of children's librarianship, were examined. These sources contained evidence that both policies which support open access and policies restricting access to information for children exist. Some aspects of relevant international and Canadian law were then analyzed to determine whether the state has imposed any limitations on children's access to information. A tension was discovered between Canada's ratification of the "United Nations Convention on the Rights of the Child," which supports open access, and a Supreme Court of Canada decision which interpreted the Canadian "Charter of Rights and Freedoms" to guarantee a parent's right to parent as an individual liberty of Canadians. Therefore, it was discovered that the rights of Canadian children to intellectual freedom and legal limitations on those rights are not yet clearly defined in Canadian law.

L'objet de cette étude était d'examiner certains aspects du problème de l'accès à l'information par les enfants dans les bibliothèques publiques au Canada. Les codes d'éthique et déclarations sur la liberté intellectuelle adoptés par deux associations professionnelles aux États-Unis (ALA) et au Canada (CLA) ainsi que les interprétations récentes et pratiques professionnelles pertinentes furent analysés. Ces sources confirment l'existence à la fois de politiques qui encouragent l'accès à l'information par les enfants et de politiques qui, au contraire, en limitent l'accès. Certains aspects du droit international et canadien furent ensuite analysés 
pour déterminer si l'état impose quelque limite sur l'accès à l'information par les enfants. Une tension fût identifiée entre la ratification par le Canada de la "Convention des Nations-Unies relative aux droits de l'enfant", qui défend le libreaccès, et une décision de la Court Suprême du Canada qui, sur la base d'une interprétation de la "Chartre canadienne des droits et libertés", a affirmée les droits parentaux des parents comme une liberté individuelle des canadiens. Il est ainsi conclu que le droit des enfants à la liberté intellectuelle au Canada, ainsi que les limites qui s'y rattachent, restent à définir dans le droit canadien.

\section{Introduction}

Provision of specialized library services for children emerged in North America at the end of the nineteenth century (Kent, Lancour, and Daily 1978). Retrospective and current standards and guidelines for service (American Library Association 1964; Gagnon 1989; Ontario Library Association 1982) and textbooks (Long 1953; Fasick 1991) confirm that the library profession regards children as falling within a unique user group with particular needs, distinguishable from other groups on the basis of age.

It has been pointed out that the act of selecting materials for a library collection results in de facto censorship in that materials not selected for inclusion are not available to users of that library (Swan 1979; Wilkinson 1997). Vandergrift (1989) notes that some public libraries have further restricted children's access to information by enforcing policies denying them access to collections developed for adult users of those libraries, thus restricting children to collections developed specifically for them.

The purpose of this paper is to examine some aspects of the issue of children's access to information through public libraries in Canada. ${ }^{2}$ While the practice of librarianship in North America is not regulated by law in the same sense as are selfgoverning and highly regulated professions (Graddy 1991), there are voluntary, semi-professional associations such as the American Library Association (ALA) and the Canadian Library Association (CLA) which promote standards for professional practice. We begin by analyzing the statements of the American and Canadian Library Associations. What position do these statements advocate for librarians serving children? These guidelines are not legally binding on Canadian librarians and, indeed, may not necessarily be in accordance with Canadian law. Therefore, current professional commentary and reported library practices will also be examined. Through this analysis we will discover that there is a tension between two views of the role of the child in society.

Law can affect the flow of information in society by acting as a boundary and setting limits on legitimate paths for information flow (Wilkinson 1992). However, 


\section{CAIS / ACSI 97}

law does not necessarily determine the outcome of every choice facing a librarian. To what extent are Canadian librarians bound by laws in this area? In the latter portion of the paper we will look at primary legal materials relevant to determining the current Canadian legal position on the role of the child in society in order to discover whether the law legitimizes either of the two approaches to the child's role apparent in the library profession.

\section{Statements of Library Associations}

While neither the ALA nor the CLA have the power to govern the behaviour of librarians, both have adopted standards for professional practice. ALA's "Code of Ethics" (American Library Association 1995, 673), the most recent version of which was adopted in 1995, supports principles of equal access to library services for all, intellectual freedom, and users' rights to privacy and confidentiality. These statements, although not identical in expression, are similar to those in the Canadian Library Association's "Code of Ethics" (Granfield 1990, 71) which was adopted in 1976.

Both groups have expanded upon the principle of intellectual freedom set out in their codes by adopting and promoting specific intellectual freedom manifestos. CLA's "Intellectual Freedom Position Statement" (1995, 22), adopted in 1974 and amended in 1983 and 1985, speaks in terms of the librarian's obligation to "all persons in Canada" and "all individuals and groups." It must be presumed to include children. ALA's "Library Bill of Rights," initially adopted in 1948 with amendments in 1961, 1967 and 1980, is more precise, stating that "a person's right to use a library should not be denied or abridged because of origin, age, background or views" (American Library Association 1996a, 43). A subsidiary ALA document, dating from 1991, "Free Access to Libraries for Minors: An Interpretation of the Library Bill of Rights," expands on this statement as follows:

Librarians and governing bodies should not resort to age restrictions on access to library resources in an effort to avoid actual or anticipated objections from parents or anyone else. The mission, goals, and objectives of libraries do not authorize librarians or governing bodies to assume, abrogate, or overrule the rights and responsibilities of parents or legal guardians. Librarians and governing bodies should maintain that parents and only parents - have the right and responsibility to restrict the access of their children - and only their children - to library resources. Parents or legal guardians who do not want their children to have access to certain library services, materials, or 
facilities, should so advise their children. Librarians and governing bodies cannot assume the role of parents or the function of parental authority in the private relationships between parent and child. Librarians and governing bodies have a public and professional obligation to provide equal access to all library resources for all library users (American Library Association 1996b, 85).

This statement does not elaborate on the rights and responsibilities of parents and guardians with respect to a child's access to information. However, it does indicate that the appropriate avenue for parental input is through the child to the librarian rather than directly from parent to librarian.

\section{Professional commentary and reported practices}

A recent, well-known text may be presumed to be reflective of current practices and therefore provides some evidence about how some libraries may be implementing the "Library Bill of Rights" in the context of children's services. Symons and Harmon, in Protecting the Right to Read: A How-To-Do-It Manual for School and Public Librarians, assert that ALA's interpretive statement has the following implications:

- parents can and should advise their own children on what they consider appropriate for them to read, hear and view;

- parents can and should enforce their wishes by dealing directly with their children;

- parents do not have the right to impose their views on other parents or other people's children;

- librarians do not and should not have the authority to monitor or restrict any patron's reading; and

- librarians who set up or adopt "restricted" library cards or practices violate the Library Bill of Rights (Symons and Harmon 1995, 11).

While this approach emphasizes the child's rights, the tension between children's and parents' rights has been a common theme in the professional literature, as exemplified by this statement by Mary K. Chelton:

In youth services librarianship, the overriding access issue is the degree to which the librarian functions in loco parentis and the degree to which youth-serving librarians should function this way. Put simply, the issue is whether the child or the parent is the primary client (Chelton 1985, 11). 


\section{CAIS / ACSI 97}

Vandergrift (1989) cites a variety of studies which show that libraries have operated in ways which limit children's access to information including requiring parental permission to borrow controversial materials, requiring parents to decide whether or not children will have access to adult collections, requiring adults to sign children's library cards and restricting children's access to some materials and services such as videos and computers. Vandergrift $(1989,396)$ maintains that "conscientious professionals may ... . be concerned about the intellectual opportunities for those young people whose parents deny them access to materials, but at least the library itself is not denying access." However, this conclusion cannot be supported. If a child wants access and a library's policy requires parental involvement, then it is the library which denies the child access in an instance of the parent's lack of involvement.

Pressures from external groups are sometimes cited as contributing to institutional restrictions (McDonald 1988). One recent example is the Family Friendly Libraries movement in the United States which has encouraged librarians to reject both the ALA "Code of Ethics" and the intellectual freedom statement and to adopt policies which would, for example, "bar unaccompanied children from accessing the adult collection and scrutinize materials for children's and YA collections for anything that might be offensive" (Harmon and Symons 1996, 62). Since adoption of the ALA or CLA codes is not required for any librarian or library system, any librarian would be free to adopt an alternative code such as the guidelines of the Family Friendly Libraries movement.

While Alvin Schrader (1995) has done much to document the decision making process surrounding public library responses to challenged materials, research is needed to determine what other policies and practices are currently in place in Canadian public libraries which impede children's access to information.

However, a Canadian example of such a restrictive institutionalized policy is the basis for one of the few reported legal decisions in Canada involving libraries. His Honour Judge Berger made a finding of fact in the case of Edmonton (City) Library Board v. Morrill that "Clinton was 14 years old at that time and the plaintiff [the Edmonton Public Library] would not issue a library card to him unless an adult accepted responsibility for the use of the card" (1989, 354-355). There is therefore, evidence in the Canadian literature that policies of both open and restricted access for children exist.

\section{Children's rights}

Sheena Scott's (1993) historical overview of children's rights describes the supremacy of the family, and the idea of the child's identity as flowing from his or her place within the family, as holding sway until about 1920 after which children 
began to be considered as having individual needs and personalities, with the idea of separate rights for children appearing some time between 1960 and 1980. Michael Freeman (1994) identifies the notion of the separate rights of children as emerging in the 1970's. As this developing idea of the rights of the child as an individual battles more traditional notions of the child's identity being bound up in the family, a clear consensus about children's rights (legal, social or philosophical), has yet to emerge in Canadian society. In this respect, any ambivalence in the library profession is but a reflection of the ambivalence in society in general.

Canada is not unique in this transitional period. In the American context, Hildebrand notes that "the concept that the child has rights apart from the parents or family is a new idea to many parents and may be hard for them to understand or accept. Furthermore, the legal precedents are not clear" $(1991,25)$.

\section{United Nations "Convention on the Rights of the Child"}

Law is territorially based. Each jurisdiction will work out its own reflection in its law of the position of the role of the child emerging in its society. Where an international consensus begins to emerge, it may be reflected in international law. The United Nations "Convention on the Rights of the Child" represents such an emerging consensus. It was adopted by the General Assembly of the United Nations in 1989 and ratified by Canada in 1991 (Forsythe 1995).

As effective sanctions for breaches of the Convention do not exist at the international level (Holmes 1990, 27), however, the real test of the effectiveness of the Convention is the degree to which its provisions have been enshrined in each nation's domestic law. Canada's adherence to this international standard is an indication of our government's intention to comply with it. Unless and until it is implemented in our domestic law, however, Canadian librarians are not bound by this international code. On the other hand, its provisions may be a very good indicator of the future direction of Canadian law in this area. To what extent has our international obligation in this area been incorporated in our Canadian law? Or, was our law already in accordance with the Convention's dictates?

The "Convention on the Rights of the Child" specifically addresses the information rights of children. Article 13, clause 1 sets out children's rights with regard to information:

The child shall have the right to freedom of expression; this right shall include freedom to seek, receive and impart information and ideas of all kinds, regardless of frontiers, either orally, in writing or in print, in the form of art, or through any other media of children's choice (Forsythe 1995, 298). 


\section{CAIS / ACSI 97}

Article 17 (Forsythe 1995, 299-300) describes the child's right to access information from diverse cultural, national and international sources and encourages the production and dissemination of children's books. It also encourages the development of guidelines to protect the child from materials injurious to his or her well-being. Articles 3, 28 and 31 also include some general provisions, such as the right of the child to participate in cultural and artistic life, which are peripherally related to the right to access information.

Article 5 describes the role of parents.

State parties shall respect the responsibilities, rights and duties of parents, or, where applicable, the members of the extended family or community as provided by local custom, legal guardians or other persons legally responsible for the child, to provide, in a manner consisting with the evolving capacities of the child, appropriate direction and guidance in the exercise by the child of the rights recognized in the present Convention (Forsythe 1995, 296).

Inherent in the Convention, then, is the same tension between the centrality of the child's rights and the need to protect the child's welfare which was apparent in the library profession's statements and practices. The child's welfare is made a state responsibility and the Convention appears to make the parent's right subordinate to the child's rights even more strongly than the ALA does in its guidelines.

\section{Canadian Law}

We turn now to ask what the position is in Canadian law with respect to the information rights of children. Does the law reflect the tenets of the international Convention?

The preamble to the CLA's "Intellectual Freedom Position Statement" includes a reference to the Canadian Charter of Rights and Freedoms (1982). Chief among the information rights stated in the Charter is the section 2(b) right to freedom of expression:

s.2 Everyone has the following fundamental freedoms:

(b) freedom of thought, belief, opinion and expression, including freedom of press and other media of communication (1982). 
This section has been interpreted by the courts to include the right of access to information (Luscher v. Deputy Minister of National Revenue 1985).

With respect to differences between Canadians based on age, the Charter specifically states:

s.15(1) Every individual is equal before and under the law and has the right to the equal protection and benefit of the law without discrimination and, in particular, without discrimination based on ... age ...(1982).

Strictly speaking, the Charter is limited to government situations (McKinney v. University of Guelph 1990). Public libraries are such situations and therefore, on its face, the Charter imposes an obligation on public libraries (and publicly funded school libraries) not to interfere with a child's access to information.

On the other hand the Charter provides for some legitimate limitations to the rights included in it. All the enumerated Charter rights including s.2(b) and s.15, are tempered by section 1 :

The Canadian Charter of Rights and Freedoms guarantees the rights and freedoms set out in it subject only to such reasonable limits prescribed by law as can be demonstrably justified in a free and democratic society (1982).

An example of a limitation on Canadians' access to information legitimized by section 1, applying to adults as well as children, is s.163(8) of the Criminal Code which defines obscene material for the purpose of criminalizing its possession and dissemination in Canada (Regina v. Butler 1992). Another is the provincial film censorship legislation (McNeil v. Nova Scotia Board of Censors 1978) which applies to public libraries though apparently not in British Columbia (Revised Statutes of British Columbia 1986, c.17, as amended) or, for some purposes, in Quebec (Revised Statutes of Quebec 1994, c.18.1). Another example of a legitimate exercise of government power limiting the s.2(b) Charter right is the prohibition in Quebec on consumer advertising aimed at all those under 13 years of age under the Quebec Consumer Protection Act. It was upheld by the Supreme Court of Canada in Irwin Toy v. Quebec (Attorney General) (1989).

Moreover, section 15(2) of the Charter authorizes certain limitations of the Charter rights declared in s.15(1) set out above.

s.15(2) Subsection (1) does not preclude any law, program or activity that has as its object amelioration of conditions of 


\section{CAIS / ACSI 97}

disadvantaged individuals or groups including those that are disadvantaged because of ... age . . . (1982).

All these examples of valid limitations on the Charter right to access information impose censorship requirements on intermediaries mediating between a child and an information source. While neither the Butler decision nor the Irwin Toy decision of the Supreme Court of Canada considered Canada's commitment to the "Convention on the Rights of the Child," these decisions appear to be consistent with Article 17(e) of that document, cited above, which encourages states to develop guidelines to protect the welfare of the child from harmful material. On the other hand, while other provisions of the United Nations Convention require that access to information be actively provided to children, as discussed above, the Charter, in the context of information access, operates in a more passive way, ensuring that access cannot be impeded, but not containing any provisions which create a positive duty to provide access.

It would appear that there is no law in Canada which specifically names the parent as a required information intermediary between the child and an information source. For example, while the Municipal Freedom of Information and Protection of Privacy Act (1990) in Ontario allows an individual with legal custody to exercise rights on behalf of a child under 16 , it does not specifically limit that right to parents as the child may also exercise the right directly. On the other hand, Canadian law does recognize that some individuals have a diminished capacity to exercise rights and, in those cases, empowers others to act on their behalf and in their stead. If this is a role being suggested for parents then the question becomes whether childhood is such a diminution of capability with respect to information handling that the law should sanction the substitution of the parent for the child. The law in Canada is complex concerning the capacity of children in various situations (Scott 1993). There is no case law which specifically discusses the capacity of children with respect to the exercise of information decisions other than in the school context (Wilson 1996).

On the other hand, there is a very recent discussion of the rights of parents in the Supreme Court of Canada in a situation involving children's rights other than information rights. The approach of the Supreme Court of Canada in that case, involving blood transfusions given to an infant against the parents' wishes (B.(R.) v. Children's Aid Society of Metropolitan Toronto 1995), may be important in future decisions involving children's access to information. The majority of the Court recognized the right to parent as part of a person's right to liberty, guaranteed under s.7 of the Canadian Charter of Rights and Freedoms. 


\section{Conclusion}

The ALA and CLA positions on intellectual freedom include children in their language. There is a competing tradition in librarianship of treating children differently from adult patrons and limiting access for these young patrons. This led us to our original question about whether Canadian law supported either of these approaches to the exclusion of the other. Hence the question in the title: Do Canadian children have a right to be intellectually free? In this brief survey we are able to point out to you that, with respect to children's rights to information, the positive obligations that Canada assumed when it ratified the United Nations "Convention on the Rights of the Child" have not yet been visibly and purposefully implemented in Canadian jurisdictions. Certain examples of Canadian legislation limiting children's access to information, which our courts have found to be constitutional, also appear to be within the limits defined by the Convention. Indeed, the Convention seems to recognize more state sanctioned limitations on the child's rights to information than the intellectual freedom manifestos of the Canadian and American Library Associations. These voluntary codes, however, do appear to go further than current domestic law in motivating the Canadian librarians who adhere to them to implement the positive obligations of the international Convention. The voluntary codes also are consistent with the international Convention in emphasizing the rights of the child over the rights of the parent to speak for the child. On the other hand, the Supreme Court of Canada has recently interpreted the Canadian Charter of Rights and Freedoms to guarantee a parent's right to parent as an individual liberty of Canadians. This may suggest that future Canadian law may limit the intellectual freedom of children by favouring parental rights. Thus the right of Canadian children to intellectual freedom, and the legal limitations on those rights (if any), are not yet clearly defined in Canadian law. This is an issue which Canadian librarians must continue to monitor. It would appear that Canadian librarians are legally free to choose either the approach of the ALA and the CLA or the Family Friendly Libraries movement: the former has support in the international Convention, the latter in the recent language of the Supreme Court of Canada on other issues involving children.

\section{Notes}

The authors wish to thank Catherine M. Simons for her contribution to this study as a research assistant.

1 Authors are listed alphabetically.

${ }^{2}$ This work is part of a larger study which is still underway.

\section{References}

American Library Association. 1964. Standards for children's services in public libraries. Chicago: American Library Association. 


\section{CAIS / ACSI 97}

1995. ALA "Code of Ethics." American Libraries 26: 673.

1996a. Library Bill of Rights. ALA handbook of organization, 1996-1997. Chicago: American Library Association.

1996b. Free access to libraries for minors: An interpretation of the library "Bill of Rights." Intellectual freedom manual. Chicago: American Library Association.

B.(R.) v. Children's Aid Society of Metropolitan Toronto. [1995]. 1 Supreme Court of Canada Reports. 315.

Canadian Charter of Rights and Freedoms. 1982. Part 1 of the Constitution Act.

Canadian Library Association. 1995. Intellectual freedom position statement. Feliciter 41: 22.

Chelton, Mary K. 1985. Issues in youth access to library services. School Library Media Quarterly 14: 21-5.

Edmonton (City) Library Board v. Morrill. (1989). 58 Dominion Law Reports (4th). 354 at 355. (Alberta Court of Queen's Bench).

Fasick, Adele M. 1991. Managing children's services in the public library. Englewood, CO: Libraries Unlimited.

Forsythe, David P., ed. 1995. Human rights in international perspective. Vol. 3, The "Convention on the Rights of the Child": United Nations lawmaking on human rights, by Lawrence J. LeBlanc. Lincoln, NE: University of Nebraska Press.

Freeman, Michael. 1994. Whither children: Protection, participation, autonomy? Manitoba Law Journal 22: 307-27.

Gagnon, Ann. 1989. Guidelines for children's services. Ottawa: Canadian Library Association.

Granfield, Diane, ed. 1990. Intellectual freedom handbook. Toronto: Ontario Library Association.

Harmon, Charles, and Ann K. Symons. 1996. But we're family friendly already: How to respond to the challenge. American Libraries 27: 60-4.

Hildebrand, Janet. 1991. Is privacy reserved for adults? Children's rights at the public library. School Library Journal 37(1): 21-5.

Holmes, John. 1990. The Convention on the Rights of the Child: A Canadian perspective. In Preserving the global environment: Proceedings of the 18th Annual Conference of the Canadian Council on International Law, held in Ottawa, 19-21 October 1989. Ottawa: Canadian Council on International Law.

Irwin Toy v. Quebec (Attorney General). (1989). 58 Dominion Law Reports 4th. 577.

Kent, Allen, Harold Lancour, and Jay E. Daily, eds. 1978. Encyclopedia of library and information science. New York: Marcel Dekker. S.v. The Pratt Institute Graduate School of Library and Information Science, by Nasser Sharify.

Long, Harriet G. 1953. Rich the treasure: Public library service to children. Chicago: American Library Association.

Luscher v. Deputy Minister of National Revenue. (Customs and Excise). [1985]. 1 Federal Court Reports. 85. (Court of Appeal).

McDonald, Frances M. 1988. Information access for youth: Issues and concerns. Library Trends 37: 2842.

McKinney v. University of Guelph. [1990]. Supreme Court of Canada. 6 Dominion Law Reports 4th. 545.

McNeil v. Nova Scotia Board of Censors. [1978]. 2 Supreme Court of Canada Reports. 62.

Municipal Freedom of Information and Protection of Privacy Act. Revised Statutes of Ontario 1990. c. M.56, as amended, s.54(c).

Ontario Library Association. 1982. Children's rights in the public library: Guidelines for service. Toronto: Ontario Library Association.

Regina V. Butler. [1992]. 1 Supreme Court of Canada Reports, 452.

Revised Statutes of British Columbia, 1986, c.17, as amended. 
Do Canadian children have the right to be intellectually free? 67

Revised Statutes of Quebec, 1994, c.18-1.

Schrader, Alvin M. 1995. Fear of words: Censorship and the public libraries of Canada. Ottawa: Canadian Library Association.

Scott, Sheena. 1993. From major to minor: An historical overview of children's rights and benefits. Journal of Law and Social Policy 9: 222-57.

Swan, John C. 1979. Librarianship is censorship. Library Journal 104 (1 October): 2040-3.

Symons, Ann K., and Charles Harmon. 1995. Protecting the right to read: A how-to-do-it manual for school and public librarians. New York: Neal-Schuman.

Vandergrift, Kay E. 1989. Are children and teenagers second-class users? Library Resources and Technical Services 33: 393-9.

Wilkinson, Margaret Ann. 1992. Impact of the Ontario Freedom of Information and Protection of Privacy Act, 1987 upon affected organizations. Ph.D. diss., University of Western Ontario. 1997. Perceptual differences in approaches to censorship: Information intermediaries and the implementation of law. The Information Society 13: 185-93.

Wilson, Jeffrey. 1996. Wilson on children and the law. Toronto: Butterworth. 